\title{
IBUFENAC IN THE TREATMENT OF ARTHRITIS
}

\author{
M. THOMPSON, P. STEPHENSON, AND J. S. PERCY* \\ From the Royal Victoria Infirmary, Newcastle upon Tyne
}

Ibufenac (4-isobutylphenyl-acetic acid, Fig. 1) has been shown to possess analgesic, anti-inflammatory, and antipyretic properties when administered to animals under experimental conditions (Adams, Cliffe, Lessel, and Nicholson, 1963). Toxicity studies indicated that this compound had a wide margin of safety, and preliminary clinical experience in patients suffering from arthritic disorders supported these findings and indicated that the therapeutic benefit was comparable to that of aspirin in rheumatoid arthritis (Chalmers, 1963; Thompson, Stephenson, and Percy, 1963). During short-term clinical trials the incidence and severity of side-effects provoked by Ibufenac were apparently less than those associated with calcium aspirin, especially in respect of gastroduodenal symptoms. Tudhope (1964) demonstrated that faecal blood loss during the administration of Ibufenac was slight in comparison with the loss occurring during aspirin therapy. Furthermore, long-term toxicity studies on experimental animals have not shown any adverse effects on either the adult animal or the foetus (Morton, 1963).

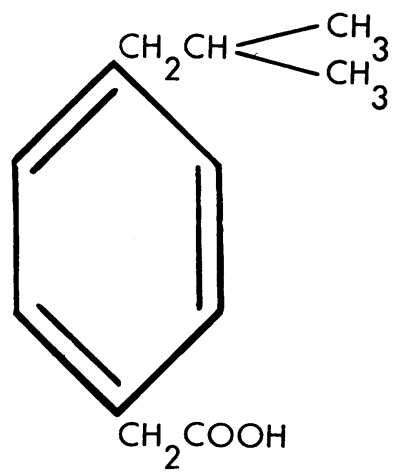

Fig. 1.-Chemical formula of Ibufenac (4-isobutyl phenyl-acetic acid).

\footnotetext{
* Arthritis and Rheumatism Council Research Fellow.
}

In view of these encouraging preliminary results, we have continued our clinical studies of the use of Ibufenac in patients suffering from arthritic disorders and the purpose of this paper is to present the results of a controlled trial, comparing Ibufenac with calcium aspirin, in patients suffering from rheumatoid arthritis, and to assess the value of Ibufenac in the long-term therapy of patients suffering from rheumatic disorders, with investigation of clinical, haematological, biochemical, and serological factors.

\section{The Controlled Trial}

The design chosen was that of a double-blind cross-over trial with sequential consideration of the results (Armitage, 1960). Ibufenac and calcium aspirin were administered in identical sugar-coated tablets in a dosage of $2.4 \mathrm{~g}$. $/ 24 \mathrm{hrs}$ for one week each. Initial allocation was determined by method of restricted randomization.

Two criteria were used for assessment of the patient's response to treatment:

(a) The patient's own expressed preference;

(b) Strength of grip, measured by the standard mercury manometric method.

Patients known to be intolerant to aspirin or those who were suffering from any disease known to be aggravated by this drug were excluded, as were patients who had recently received steroid therapy and those with such deformity of the hand as to make improvement in grip unlikely.

The differences in strength of grip were analysed by the sequential method described by Hajnal, Sharp, and Popert (1959). Ibufenac was shown to be significantly more effective than aspirin in improving grip, after the results from fifty patients had been considered (Fig. 2, overleaf ). 


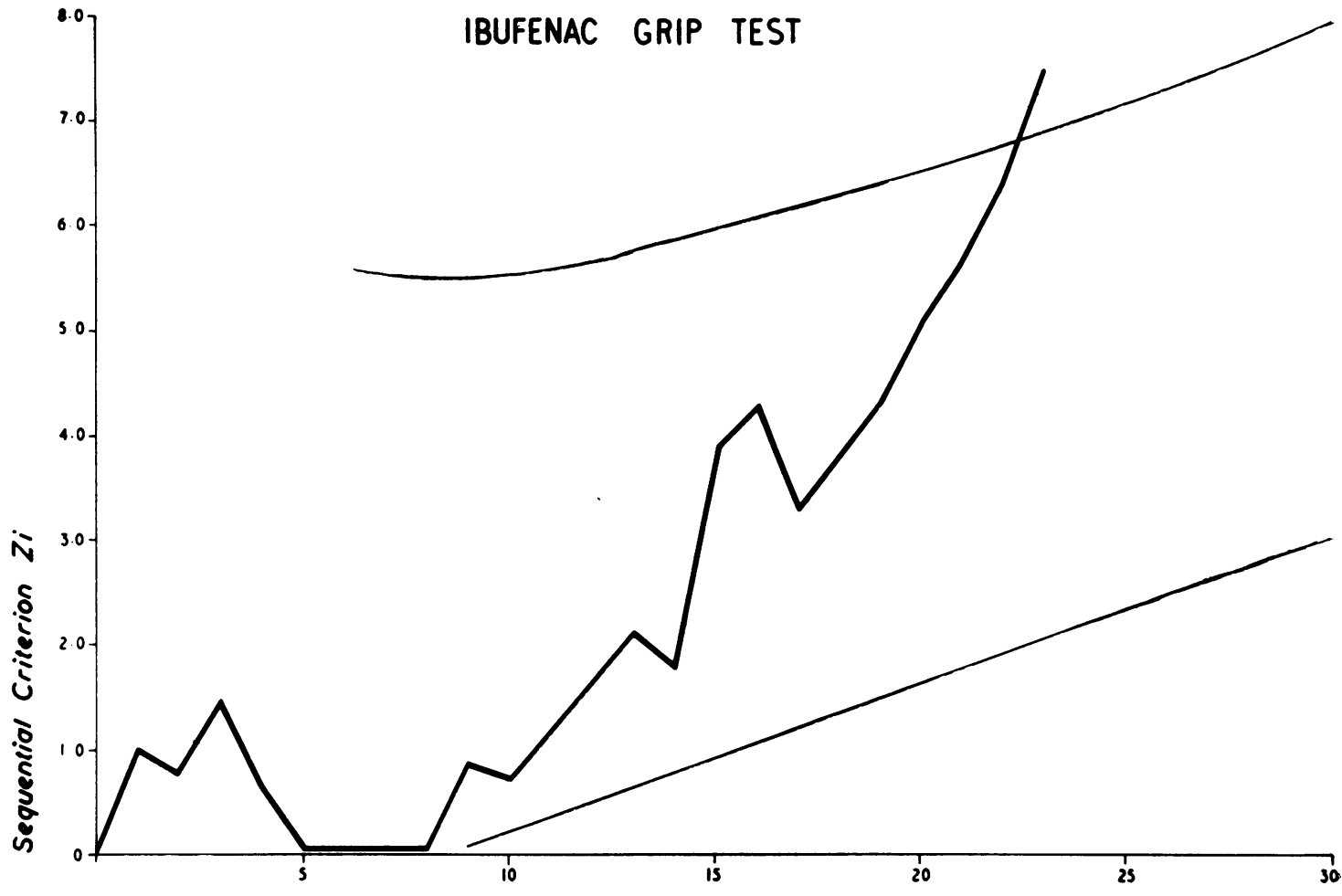

\section{No. of poirs of Patients}

Fig. 2.-Result of grip tests, indicating significant improvement given by Ibufenac in comparison with calcium aspirin.

The patients preferences were charted on a graph designed to show at the conventional 5 per cent. significance level, whether or not there was a difference in preference ratio of the order $8: 2 ; 35$ patients expressed a preference before the boundary, showing in favour of Ibufenac, was crossed, 26 (74 per cent.) of the patients having declared a preference for the week of Ibufenac therapy (Fig. 3, opposite).

Side-effects.-Fourteen ( 26 per cent.) patients complained of side-effects whilst taking aspirin and eight (15 per cent.) while taking Ibufenac. The comparative severity of the side-effects was, however, more marked than these figures suggest (Table).

Continuous Treatment.-In view of the superiority of Ibufenac over calcium aspirin as demonstrated by the controlled trial, further clinical studies were undertaken, and so far 45 patients have been treated for periods ranging from 1 to 16 months (average $6 \frac{1}{2}$ months). The dosage has ranged from $750 \mathrm{mg}$. to $5 \mathrm{~g}$. daily (average $2 \cdot 5 \mathrm{~g}$.) given in divided dosage. All other therapy was withdrawn when the patients commenced treatment with Ibufenac, the only exceptions being methyl-dopa taken by one patient and
TABLE

SIDE-EFFECTS COMPLAINED OF BY 54 PATIENTS DURING A CONTROLLED TRIAL OF IBUFENAC $V$. ASPIRIN

\begin{tabular}{|c|c|c|c|c|c|}
\hline \multirow{2}{*}{\multicolumn{4}{|c|}{ Side-Effects }} & \multicolumn{2}{|c|}{ Drug } \\
\hline & & & & Ibufenac & Aspirin \\
\hline Epigastric Pain & & $\begin{array}{l}\text { Severe } \\
\text { Mild }\end{array}$ & $\ldots$ & $\begin{array}{l}\mathbf{0} \\
\mathbf{3}\end{array}$ & $\begin{array}{r}10 \\
0\end{array}$ \\
\hline $\begin{array}{l}\text { Nausea .. } \\
\text { Flatulence } \\
\text { Vertigo . . }\end{array}$ & $\begin{array}{l}\cdots \\
\cdots\end{array}$ & $\begin{array}{l}\cdots \\
\cdots \\
\cdots\end{array}$ & $\begin{array}{l}\cdots \\
\cdots \\
\cdots\end{array}$ & $\begin{array}{l}3 \\
6 \\
0\end{array}$ & $\begin{array}{l}8 \\
2 \\
2\end{array}$ \\
\hline Total Complaints & $\ldots$ & $\ldots$ & $\ldots$ & 12 & 22 \\
\hline No. of Patients wh & $\mathrm{mp}$ & ained & $\ldots$ & 8 & 14 \\
\hline
\end{tabular}

methyl-prednisolone taken by another. All patients were reviewed at monthly intervals.

\section{Results}

Duration of Morning Stiffness.-This was recorded in thirty patients. It remained unchanged in eleven, worsened in two, and improved in seventeen. The average duration of stiffness at the start of treatment was $1 \frac{3}{4}$ hours (range $10 \mathrm{~min}$. to $6 \mathrm{hrs}$ ) and at the last assessment the average was $1 \mathrm{hr}$ (range nil to $4 \mathrm{hrs}$ ). 


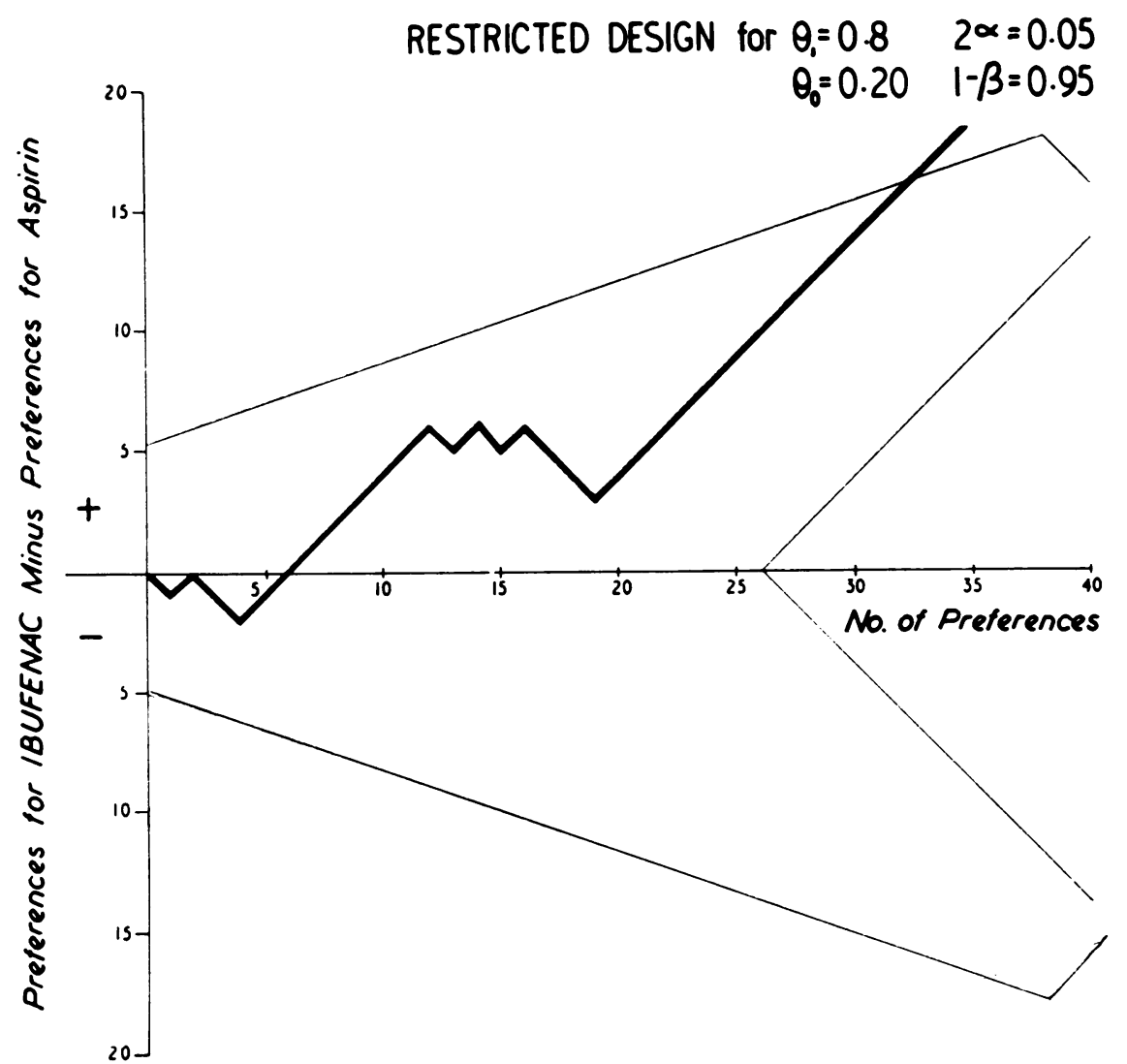

Fig. 3.-Result of controlled trial indicating significant preference for Ibufenac over calcium aspirin in terms of symptomatic relief.

The average percentage reduction was 30 per cent. When statistically tested by Wilcoxon's signed rank T test (Wilcoxon, 1945), this was found to be a significant change.

Strength of Grip.-This was measured in 26 patients, using the mercury manometer method, and the mean of three readings was taken for each hand. Of these 26 patients, thirteen showed improvement in grip, three remained static, and ten showed deterioration. When the results were analysed by Wilcoxon's test, the improvement was found to be significant.

Body Weight.-This was charted in 29 patients, none of whom was taking a special diet. The average weight gain was $2 \frac{1}{2} \mathrm{lb} .(1 \cdot 25 \mathrm{~kg}$.); eighteen patients gained, three remained the same, and eight lost weight. The weight gain was shown to be statistically significant and there was no clinical or laboratory evidence to suggest that it could be due to fluid retention. The most striking weight gain occurred in those patients who claimed an increased sense of well-being and improvement in appetite while taking Ibufenac.

Erythrocyte Sedimentation Rate (Westergren).This was studied in 33 patients. The average reading at the start of therapy was $24 \mathrm{~mm}$. $\mathrm{Hg}$ (range 5 to 98 ) in one hour. At the time of the last review the average was $9 \mathrm{~mm}$. (range 1 to 40 ). This fall was found to be highly significant $(P<0.001)$ when examined by Wilcoxon's test.

Dyspepsia.-Of the 45 patients treated, thirty had a history of dyspepsia whilst taking their previous analgesic, and nine of these patients had proven gastro-duodenal ulceration. Of this group of thirty, 26 claimed relief from dyspepsia while taking Ibufenac; the remaining four patients had persistent dyspepsia due to duodenal ulceration whether they were taking analgesics or not, but all four stated that the dyspepsia was considerably less during Ibufenac therapy than when they were taking other preparations. In no case did the dyspepsia increase while the patient was taking Ibufenac nor, to date, 
has dyspepsia developed in a previously eupeptic subject.

Occult Blood in Faeces.-Tests were performed on 44 occasions in sixteen patients. Eight positive results were obtained in five patients, but only two of them gave consecutively positive results.

No significant changes were noted in bloodpressure and on urine analysis (30 patients); haemoglobin and white cell counts (33 patients); serum electrolytes and blood urea (30 patients); serum proteins and electrophoretic patterns (9 patients); Waaler-Rose titre (29 patients).

Serum Uric Acid.-Serial estimations were undertaken in 43 patients, of whom 22 demonstrated levels above the upper limit of normal $(6 \mathrm{mg} . / 100 \mathrm{ml}$.) on more than one occasion, and values in excess of 7 mg. were found in thirteen patients. The highest serum uric acid recorded in the series was $9.4 \mathrm{mg}$. In six patients the rise was transient and normal levels were obtained during continued administration of the drug. In the other sixteen patients, the serum uric acid returned to normal levels within 3 months of withdrawing the drug in twelve cases, but in the remaining four ( 2 male and 2 female) there has been persistent hyperuricaemia for more than 4 months since cessation of therapy. There has been no constant relationship between the degree of hyperuricaemia and the dosage of the drug, nor did duration of treatment appear to be a determining factor, as several patients showed a striking rise in serum uric acid levels within 2 months of starting therapy. To date there have not been any evident adverse effects ascribable to hyperuricaemia in these patients.

Liver Function Tests.-These were performed at monthly intervals in 36 patients, and abnormalities were demonstrated in fourteen, including gross changes associated with jaundice in two patients. In twelve patients there was elevation of the serum glutamic oxalo-acetic transaminase level (S.G.O.T., normal upper limit $=40$ Sigma-Frankel units) or of the serum glutamic pyruvic transaminase level (S.G.P.T., normal upper limit $=35$ Sigma-Frankel units). In four patients the rise in S.G.O.T. was transient and normal levels were restored while treatment continued. The S.G.O.T. and S.G.P.T. levels in the remaining ten patients slowly returned to normal levels following withdrawal of the drug.

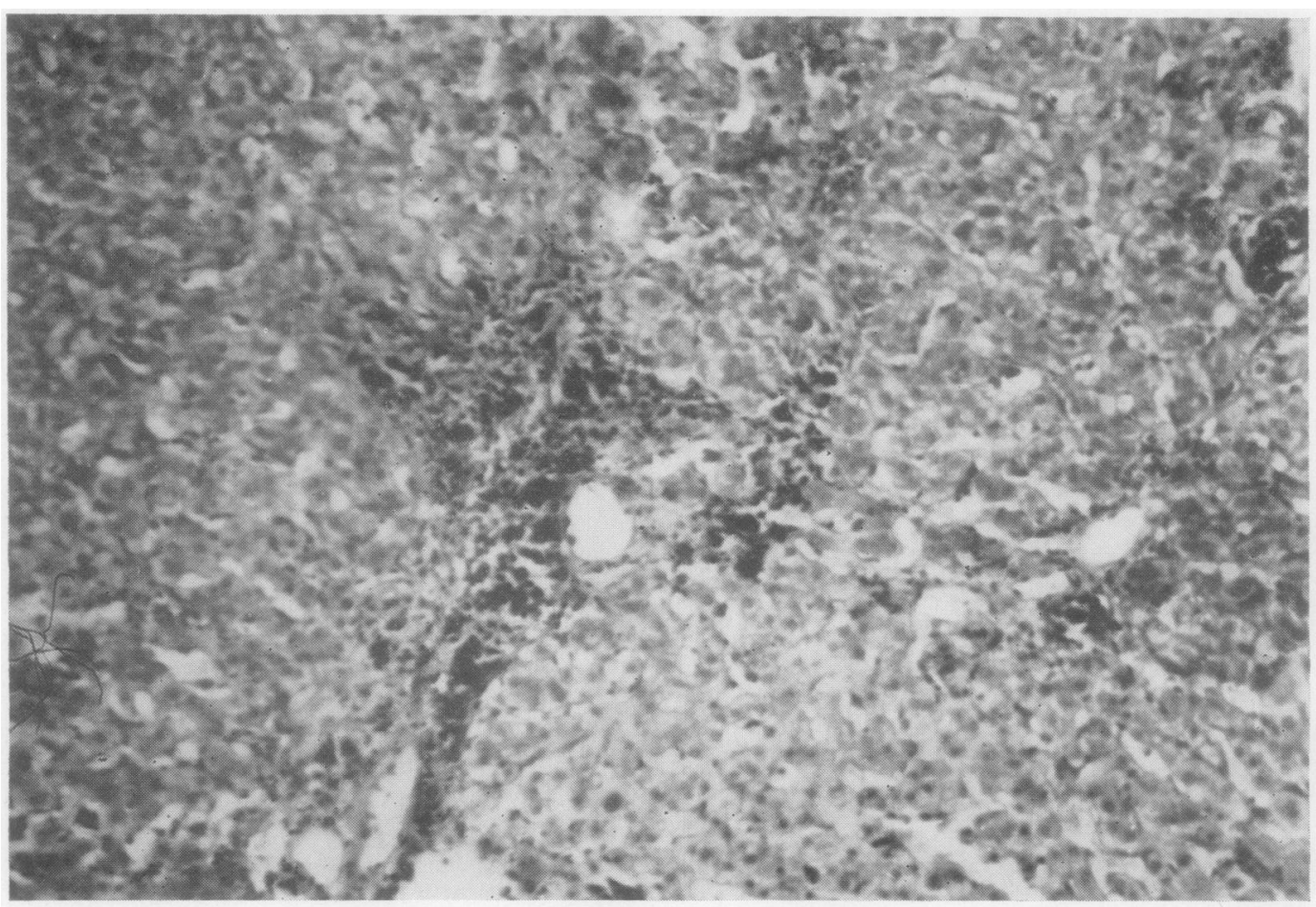

Fig. 4.-Case 1. Section from liver biopsy, showing infiltration of a portal tract by lymphocytes and plasma cells, and also the presence of numerous macrophages. There is no evidence of intra-hepatic cholestasis. PAS-diastase. $\times 165$. 
Two of these fourteen patients also demonstrated slight and transient rises in serum bilirubin levels, to $0.9 \mathrm{mg}$. per $100 \mathrm{ml}$., and three had raised levels of serum alkaline phosphatase at some time during therapy.

In one patient in whom the S.G.O.T. had risen to 90 units, the serum lactic dehydrogenase was estimated and was found to be raised to 790 units (normal range 250 to 650 units). Electrophoretic studies of the serum lactic dehydrogenase in this patient (Prof. A. L. Latner) indicated that the increase was due to the hepatic iso-enzyme component.

The case histories of the two patients who developed jaundice are briefly presented.

Case 1, a laboratory assistant aged 63, had suffered from rheumatoid arthritis for 9 years. He experienced dyspepsia while taking aspirin preparations, and treatment by Ibufenac was commenced on May 8, 1963, in a dosage of $2 \mathrm{~g}$. daily. There was an initially good therapeutic response without dyspepsia, and liver function tests on June 5 were satisfactory, as the only abnormalities were in the zinc sulphate, thymol turbidity, and cephalin cholesterol tests which could be ascribed to protein changes in rheumatoid arthritis. Dosage of Ibufenac was raised to $3 \mathrm{~g}$. daily on July 3 and further improvement was obtained with the increased dosage. On August 5 the S.G.O.T. level was found to be raised to 110 units and by August 28 it had risen to 312 units and the S.G.P.T. was 240 units, at which point Ibufenac was withdrawn. The serum bilirubin was $0.9 \mathrm{mg}$., but rose to $1.4 \mathrm{mg}$. during the next few days; mild icterus developed on September 11 and the patient was admitted to hospital. The S.G.O.T. was now 680 units and S.G.P.T. 460 units and the patient was symptom-free despite the mild icterus. The liver edge was not palpable nor tender.

Percutaneous liver biopsy was performed on September 23 (Dr. D. N. S. Kerr) and histological examination of the tissue obtained was reported by Dr. A. J. Watson:

"There is preservation of the normal architecture. The portal tracts are infiltrated by lymphocytes and plasma cells and contain numerous macrophages with an orange granular cytoplasm (in haematoxylin

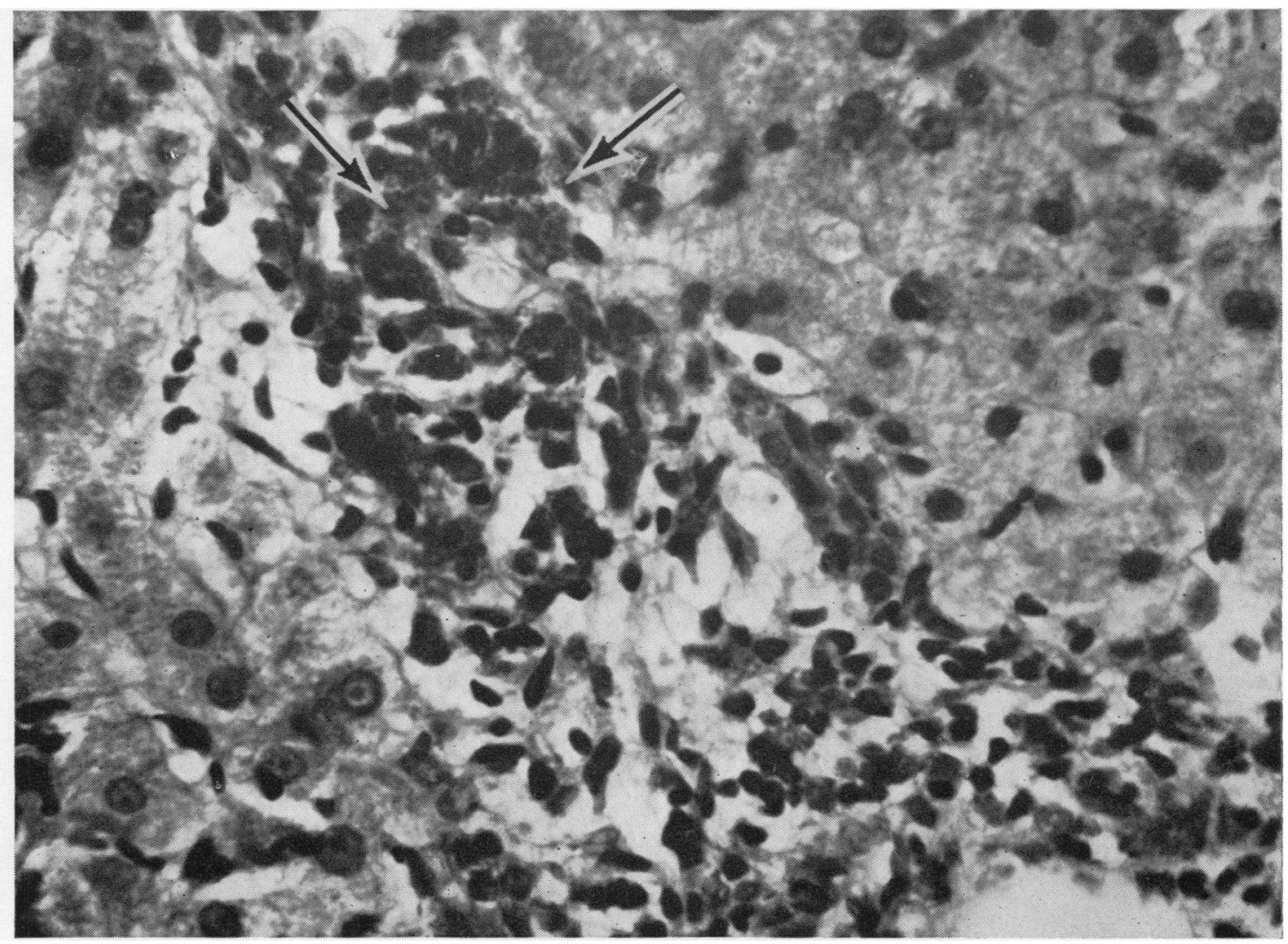

Fig. 5.-High-power view of the region of a portal venule and portal tract taken from Fig. 4. Granular material (arrowed) is seen within the macrophages. PAS-diastase. $\times 600$ 
and eosin section). These granules are yellow in unstained sections and remain periodic acid-Schiffpositive after diastase treatment. Occasional Kupffer cells show a similar appearance but most are normal. The liver parenchymal cells show an increase in regenerative activity. There is no evidence of bile stasis."

The histological appearances are shown in a P.A.S.diastase treated section (Figs 4 and 5).

The patient made an uneventful recovery from jaundice and the hepatic function tests reverted to normal limits within 3 months of withdrawal of treatment. This patient had received a total dosage of $250 \mathrm{~g}$. Ibufenac over 111 days.

Case 2, a secretary aged $\mathbf{4 5}$ years, had a history of acute onset of rheumatoid arthritis of 2 months duration. In view of inadequate response to and dyspepsia during aspirin therapy, treatment with Ibufenac in a dosage of 2 g. daily was commenced on June 14 . At this time liver function tests were normal, the S.G.O.T. being 22 units. On July 12 the dosage was increased to $3 \mathrm{~g}$. daily and at this time the patient was feeling improved and liver function tests were still satisfactory, the S.G.O.T. being 35 units. The S.G.O.T. rose to 50 units on August 9 and by September 13 it had risen to 1020 units and the S.G.P.T. to 1100 units. The patient was symptom-free until September 16, when mild nausea and anorexia developed and on September 18 slight icterus was apparent. The liver edge was just palpable, being smooth and firm but not tender. The patient was admitted to hospital, having taken $285 \mathrm{~g}$. Ibufenac during 101 days of treatment.

The S.G.O.T. and S.G.P.T. rose to peak values of 1160 and 1250 units respectively on September 23 and the serum bilirubin was 1.9 , jaundice now being evident. Serum bilirubin levels rose to $4.9 \mathrm{mg}$. on September 27 but thereafter fell, and the level was $1.4 \mathrm{mg}$. on October 7 when the S.G.O.T. was 440 units and S.G.P.T. 400 units. Nausea persisted but vomiting was controlled by cyclizine. The S.G.O.T. and S.G.P.T. levels fell further to 50 and 53 units respectively by November 15 . The jaundice had faded completely 18 days after it appeared, but mild anorexia persisted for several weeks after this.

\section{Discussion}

The results of the controlled trial, comparing one week of Ibufenac therapy with one week of calcium aspirin in the treatment of patients suffering from rheumatoid arthritis, indicated that Ibufenac was not only superior in its clinical effect but that the incidence and severity of side-effects in such shortterm therapy was less than those encountered with calcium aspirin. These findings substantiated the results obtained in short-term clinical trials by Chalmers (1963), and supported the view that Ibufenac could be of value in the treatment of rheumatoid arthritis. Additional support was given by the early results of continuous treatment, when such indices of improvement as decreased morning stiffness, improved grip strength, weight gain, and reduction of the erythrocyte sedimentation rate, showed a significantly favourable response to Ibufenac therapy. Furthermore, there was a gratifying reduction of dyspepsia in those patients previously subject to this, and the low incidence of faecal blood loss noted by examinations for occult blood was in keeping with the observations of Tudhope (1964), who used erythrocytes labelled with radio-active chromium to estimate faecal blood loss during Ibufenac therapy.

In the assessment of the value of any drug in the treatment of chronic arthritic disorders, such factors as freedom from serious toxic properties and simplicity of supervision during long-term administration are as important as demonstration of therapeutic value. Hitherto the only adverse side effect of Ibufenac was a rash noted in three patients Morton (1963). As one of these patients was known to be allergic to several drugs and another had a localized rash, and in all three the signs cleared rapidly after withdrawal of Ibufenac, this rash was not considered to be a serious hazard. However, our observations of disturbances in liver function during treatment with Ibufenac indicated that the drug was hepatotoxic. The occurrence of raised S.G.O.T. titres in fourteen patients out of 36 investigated, even though the rise was only transient in four, was strongly suggestive? evidence. The demonstration that a concurrent elevation of lactic dehydrogenase in one patient was due to a hepatic isoenzyme was further evidence that the elevations of S.G.O.T. and S.G.P.T. could be due to hepatic dysfunction. Additional and conclusive proof was provided by the occurrence of jaundice in two patients who had developed extremely high levels of S.G.O.T. and S.G.P.T. We have also received reports concerning three additional cases of jaundice in approximately $4 \mathrm{CO}$ patients receiving Ibufenac in various rheumatic clinics in Great Britain (Personal communications).

Although our two patients who developed jaundice ran a mild course with fairly rapid clearing of the icterus and return of liver function tests to normal within a few weeks of the withdrawal of Ibufenac, the occurrence of hepatotoxicity imposes a serious limitation on the use of this drug in the long-term treatment of rheumatoid arthritis. Other drugs used in the treatment of rheumatoid arthritis may cause liver damage-e.g. phenylbutazone, which does so but rarely, and gold, which has lost favour as a result of this and other side-effects. Aspirin and sodium salicylate may cause elevations of S.G.O.T. and S.G.P.T. (Manso, Taranta, and Nydick, 1956; Drivsholm and Madsen, 1961; 
Wilkinson, 1962), but the elevations were not gross and none of these authors noted jaundice in any of their patients.

The occurrence of hepatotoxicity with Ibufenac could not have been anticipated on the basis of the results of animal studies conducted before the drug was made available for clinical trials. Dogs were given large doses up to $160 \mathrm{mg} . / \mathrm{kg}$. and much in excess of the $35 \mathrm{mg} . / \mathrm{kg}$. usually employed in treatment, and after 26 weeks there was neither biochemical nor histological evidence of any liver changes. In rats there was evidence of generalized organ enlargement involving the liver and kidneys when doses in the order of 100 and $250 \mathrm{mg}$. $/ \mathrm{kg}$. were given for 27 weeks, but no evidence of liver cell damage was noted on histological examination. Doses of 625 and $1,000 \mathrm{mg}$. $/ \mathrm{kg}$. for 27 weeks produced evidence of cellular damage in the liver and other tissues; there was, however, no indication of primary liver toxicity in these animals (Morton, 1963).

The rise in serum uric acid was also unexpected, and the significance of this finding was not clear. No urinary abnormalities were encountered during treatment and no ill-effects from hyperuricaemia were noted. There was no relationship between evidence of hepatic dysfunction and rise in serum uric acid. Five of the fourteen patients who had raised transaminase levels also had raised serum uric acid levels at the same time, but not always concurrently, and this could well have been a chance relationship. The finding of deposits of granular material in the liver macrophages suggested the possibility that this might be precipitated drug or metabolites responsible for the hepatic dysfunction, but the lack of any specific staining for Ibufenac prevented the testing of this hypothesis. Nor was it possible to determine whether granules were present in renal tissue in man.

\section{Summary}

Ibufenac (4-isobutylphenylacetic acid) was compared with calcium aspirin in the treatment of rheumatoid arthritis, and the results of one week of therapy with each in a controlled trial were analysed by a sequential method. Ibufenac was shown to be superior to calcium aspirin in terms of relief of symptoms and improvement in strength of grip. The incidence of side-effects in such shortterm therapy was less during treatment with Ibufenac.

Further clinical experience in the treatment of 45 patients over periods ranging from 1 to 16 months showed significant improvement in morning stiffness, strength of grip, gain in weight, and reduction of erythrocyte sedimentation rate. The incidence of dyspepsia in this group of patients was reduced in comparison with previous therapy and faecal occult blood loss was slight in sixteen patients tested.

The only side-effect of clinical significance in this series has been evidence of liver dysfunction, in fourteen out of 36 patients investigated, and jaundice in two patients. Definite hyperuricaemia was noted in thirteen patients and mild hyperuricaemia in a further nine out of 43 investigated.

The occurrence of hepatotoxicity to the extent noted in this series is considered to impose a considerable limitation upon the use of Ibufenac, and to constitute a contraindication to its unrestricted use in long-term treatment.

We wish to thank Dr. E. V. B. Morton and Dr. S. S. Adams, of Boots Pure Drug Co., for supplies of Ibufenac and for their advice. We also acknowledge the help of Mr. H. H. Poole, Chief Pharmacist at the Royal Victoria Infirmary, and the assistance of Nurse A. Kinghorn, Miss P. Port, and Miss E. A. Evans.

\section{REFERENCES}

Adams, S. S., Cliffe, E. E., Lessel, B., and Nicholson, J. S. (1963). Nature (Lond.), 200, 271.

Armitage, P. (1960). "Sequential Medical Trials". Blackwell, Oxford.

Chalmers, T. M. (1963). Ann. rheum. Dis., 22, 358.

Drivsholm, Aa., and Madsen, S. (1961). Scand. J. clin. Lab. Invest., 13, 442.

Hajnal, J., Sharp, J., and Popert, A. J. (1959). Ann. rheum. Dis., 18, 189.

Manso, C., Taranta, A., and Nydick, I. (1956). Proc. Soc. exp. biol. (N.Y.), 93, 84 .

Morton, E. V. B. (1963). Personal communication.

Thompson, M., Stephenson, P., and Percy, J. (1963). Paper presented at Fifth European Congress on Rheumatic Diseases, Stockholm.

Tudhope, G. R. (1964). Ann. rheum. Dis., 23, 30.

Wilcoxon, F. (1945). Biometrics Bull., 1, 80.

Wilkinson, J. H. (1962). "An Introduction to Diagnostic Enzymology”, p. 131. Arnold, London.

\section{Ibufenac dans le traitement de l'arthrite}

\section{RÉSUMÉ}

On a comparé Ibufenac (acide 4-isobutylphénylacétique) à l'aspirine-calcium dans le traitement de l'arthrite rhumatismale et on a analysé par la méthode séquentielle les résultats d'un essai contrôlé de thérapie par chaque médicament pendant une semaine. Ibufenac s'est montré supérieur à l'aspirine-calcium en ce qui concerne le soulagement symptomatique et la force de l'étreinte. La fréquence des effets secondaires pendant cette courte période de thérapie était moindre avec Ibufenac.

Un autre essai de ce médicament chez 45 malades pendant une période s'étendant de 1 à 16 mois révéla une amélioration significative de l'enraidissement matinal et de la force de l'étreinte, une augmentation du poids corporel et une réduction de la vitesse de sédimentation érythrocytaire. La fréquence de la dyspepsie dans ce 
groupe de malades était réduite par rapport au traitement précédant et la perte sanguine occulte par les fèces était peu importante chez les 16 malades examinés de ce point de vue.

Le seul effet secondaire d'importance clinique dans cette série fut la fonction hépatique défectueuse chez 14 sur 36 malades examinés à cet effet; deux d'entre eux eurent un ictère. Sur 43 malades examinés, 13 accusèrent une hyperuricémie franche et 9 autres une hyperuricémie légère.

On considère que la fréquence de la toxicité hépatique notée dans cette série impose une limitation considérable à l'emploi d'Ibufenac et contre-indique un traitement prolongé et sans restriction par ce produit.

\section{Ibufenac en el tratamiento de artritis}

\section{SUMARIO}

Se comparó Ibufenac (ácido 4-isobutilfenilacético) a la aspirina cálcica en el tratamiento de la artritis reumatoide y se analizaron por el método secuencial los resultados de un ensayo controlado de terapia con cada producto durante una semana. Ibufenac resultó ser superior a la aspirina cálcica respecto al alivio sintomático y a la fuerza de la mano. La frecuencia de efectos secundarios durante este corto período de terapia fué menor con Ibufenac.

Un otro ensayo de este fármaco en 45 enfermos durante períodos de uno a 16 meses reveló una mejoría significativa de la rigidez matinal y de la fuerza de la mano, un aumento de peso y una reducción de la velocidad de sedimentación eritrocitaria. La frecuencia de la dispepsia en este grupo de enfermos se vió reducida en comparación con el tratamiento anterior y la pérdida de sangre fecal oculta fué poquísima en los 16 enfermos examinados desde este punto de vista.

El único efecto secundario de importancia clínica en esta serie fué la disfunción hepática observada en 14 de los 36 enfermos investigados en este respecto; dos de aquellos desempeñaron ictericia. De los 43 enfermos investigados, 13 acusaron hiperuricemia franca y 9 hiperuricemia ligera.

Se considera que la frecuencia de la toxicidad hepática observada en este serie impone limites considerables al empleo de Ibufenac y contraindica un tratamiento prolongado y sin restricción con este producto. 